\title{
Background matching behaviour and pathogen acquisition: plant site preference does not predict the bacterial acquisition efficiency of vectors
}

\author{
Arash Rashed $\cdot$ Nabil Killiny $\cdot$ Joyce Kwan • \\ Rodrigo P. P. Almeida
}

Received: 25 September 2010/ Accepted: 6 December 2010/Published online: 24 December 2010

(C) The Author(s) 2010. This article is published with open access at Springerlink.com

\begin{abstract}
Many insect-borne pathogens are heterogeneously distributed within their hosts: therefore, a vector's within-plant distribution may be a predictor of its exposure to pathogens. In this study, we set out to quantify plant site preference, in the context of background matching, and investigated its effect on acquisition of a bacterial pathogen by its leafhopper vectors. The two green-coloured species, Graphocephala atropunctata and Draeculacephala minerva, preferred green plant tissue and artificial backgrounds whereas the brown-coloured Homalodisca vitripennis preferred brown stem tissue and backgrounds. Within-plant feeding site did not predict either the acquisition success or the number of plant-pathogenic Xylella fastidiosa cells acquired by the vectors; an $86 \%$ mortality for $G$. atropunctata was reported on the lignified stem tissue. Overall, $H$. vitripennis acquired significantly more cells than G. atropunctata. A novel artificial diet-based transmission system was used to further illustrate that the observed between-species difference in the number of cells acquired was independent of vector-host plant interactions. $H$. vitripennis, a less efficient vector of the bacterium $X$. fastidiosa on grapevines, acquired more bacterial cells than G. atropunctata, possibly due to its larger size. Contrary to previous assumptions, pathogen acquisition efficiency by the vectors did not explain their reported differences in inoculation. Vector interactions with the host
\end{abstract}

Handling Editor: Guy Smagghe.

A. Rashed ( $ه) \cdot$ N. Killiny · J. Kwan · R. P. P. Almeida Department of Environmental Science, Policy \& Management, University of California, 137 Mulford Hall,

Berkeley, CA 94720, USA

e-mail: arashed@berkeley.edu during the inoculation stage should be evaluated as another determinant of $X$. fastidiosa transmission efficiency.

Keywords Acquisition efficiency $\cdot$ Background matching · Plant site preference - Transmission - Vector behaviour $\cdot$ Vector-borne pathogen

\section{Introduction}

Vector host choice (Blua and Perring 1992; McElhany et al. 1995; Alvarez et al. 2007) and within-host feedingsite preference (Tsai et al. 2002; Marucci et al. 2004) can influence patterns of vector-borne pathogen distribution and disease dynamics (McElhany et al. 1995; Kilpatrick et al. 2006; Sisterson 2008). Moreover, variations in feeding behaviour among species may also contribute to the existing differential transmission efficiency of vectors (Turell et al. 2001; Daugherty and Almeida 2009) through governing the degree to which they are exposed to a pathogen. Differential exposure may result from the heterogeneous distribution of pathogens, either temporally or spatially, among and/or within host species (Dekker et al. 1998; Saracco et al. 2005; Shriram et al. 2005; Kilpatrick et al. 2006; Tatineni et al. 2008). Furthermore, while feeding behaviour may affect vector exposure to pathogens, it also affects an individual's exposure to would-be predators present in the surrounding environment. Such selection pressure facilitates the evolution of protective morphological traits and their associated behaviours, which maximize their adaptive function (Fisher 1930). For example, whereas adopted movement patterns can maximize the effectiveness of protective aposematic and mimetic traits (Chai and Srygley 1990; Hatle et al. 2002; Sherratt et al. 2004), background matching —a resemblance 
of body coloration to a random sample of the immediate background (Endler 1984) - is most effective when the bearer has limited mobility within its specialized homogeneous environment (see Cott 1940; Cloarec and Joly 1988; Stamp and Wilkens 1993; Ioannou and Krause 2009). Therefore, it is plausible that evolving protective traits that increase vectors' fitness according to their foraging and feeding modes may affect their transmission efficiency.

Limited information exists on the role of within-host plant site preference in the transmission of vector-borne pathogens. Most recently, Daugherty et al. (2010) experimentally showed that plant site preference of xylem-sap feeding sharpshooter leafhopper vectors (Hemiptera: Cicadellidae) is linked to their efficiency in transmitting the plant pathogenic bacterium Xylella fastidiosa. X. fastidiosa attaches to and colonizes the cuticular surface of the vector's foregut (Almeida and Purcell 2006) and causes various diseases in a wide range of host plants; one of the prominent examples is Pierce's disease of grapevines (Hopkins and Purcell 2002).

Due to the poor nutritional content of the xylem-sap (Andersen et al. 1992; Mizell et al. 2008), sharpshooter vectors spend from 1 to several hours continuously ingesting xylem-sap (Almeida and Backus 2004; Backus et al. 2005), which consists of more than $98 \%$ water and very low concentrations of carbohydrates (Mizell et al. 2008). Homalodisca vitripennis (Germar), for example, consumes between 10 and 100 times its dry body-weight hourly (see Redak et al. 2004). During such lengthy feeding episodes sharpshooters are exposed to a range of visual predators including jumping spiders (Salticidae), assassin bugs (Hemiptera: Reduviidae), lizards (Lopez et al. 2003; Suttle and Hoddle 2006; Fournier et al. 2008), and potentially insectivorous birds (Burger et al. 1999).

Although extensive colour and size variations exist among sharpshooter leafhopper species, studies are lacking which examine the precise function of colour patterns and their potential effect on the transmission efficiency of $X$. fastidiosa. Here, we evaluated the background matching behaviour of three species of sharpshooter leafhoppers, H. vitripennis, Draeculacephala minerva (Ball), and Graphocephala atropunctata (Signoret), all of which are vectors of $X$. fastidiosa. H. vitripennis in southern California was first reported on a range of hosts including citrus trees (Sorenson and Grill 1996; Hopkins and Purcell 2002) and subsequently caused severe damage in vineyards due to its role in spreading $X$. fastidiosa among grapevines (Hopkins and Purcell 2002). G. atropunctata is found on riparian woody plants such as grapevines and various ornamental shrubs of coastal California and is blue-green in colour (Purcell 1976). The green-coloured D. minerva is abundant in moist habitat of grasses and weedy plants in
California (Purcell and Frazier 1985). In addition to differences in their preferred host range, sharpshooter species also vary in their within-plant feeding site. In grapevines, for example, while it has been observed that $H$. vitripennis feeds primarily on the stem, G. atropunctata feeds on leaf blades and petioles (Redak et al. 2004). In alfalfa, the apical parts of the plant are also the preferred feeding site of $G$. atropunctata, while D. minerva tends to exploit the basal stem tissue (Daugherty et al. 2010).

Xylella fastidiosa is not evenly distributed within its host plants; in grape, it colonizes leaves and petioles with higher populations than the stem tissue (Krivanek and Walker 2005). It has also been shown that $X$. fastidiosa transmission efficiency depends on the level of infection in the source plants (Hill and Purcell 1997). Compared to $H$. vitripennis, G. atropunctata is a more efficient vector of $X$. fastidiosa in grapevines (Purcell and Saunders 1999; Almeida and Purcell 2003). Thus, it is possible that differences among sharpshooter species in transmission efficiency of $X$. fastidiosa (e.g. Redak et al. 2004) arise simply due to their differential exposure to the pathogen at their preferred feeding sites (Daugherty et al. 2010). To test this, one must show that the acquisition efficiency of vectors is affected by feeding site. In this paper the term 'acquisition efficiency' is a factor of both acquisition rate (or the proportion of vectors that successfully acquire the pathogen), and the number of bacterial cells acquired per vector (hereafter referred to as 'acquisition level').

We first tested whether three sharpshooter vectors of X. fastidiosa-D. minerva, G. atropunctata, and H. vitripennis-are selective in their landing site within grapevines. Second, in an artificial arena we investigated whether plant site preference can be explained by background matching in these species. In the case of background matching, sharpshooters are expected to be selective for backgrounds that closely match their bodycolour. Finally, we conducted both in planta and in vitro no-choice feeding trials for $H$. vitripennis and $G$. atropunctata to evaluate whether bacterial acquisition efficiency is linked to the plant site where feeding occurs.

\section{Materials and methods}

\section{Experimental insects}

A laboratory population of $H$. vitripennis was initiated with field-collected insects from Fillmore, CA, in 2009. Multiple tent-shaped, $60 \mathrm{~cm} \times 60 \mathrm{~cm} \times 60 \mathrm{~cm}$ bugdorms (BioQuip, Rancho Dominquez, CA, USA) were set up, each seeded with 90-120 male and female adults. Four to six large basil (Ocimum basilicum, Lamiaceae) plants were placed in each of the bugdorms to provide ample feeding 
and oviposition sites for the sharpshooters (basil is a poor host for X. fastidiosa; RPPA, unpublished data). Plants were replaced every $2-3$ weeks. Field-collected insects were used in choice experiments within 8 weeks of collection, with the exception of $D$. minerva. The $D$. minerva colony had been maintained in a greenhouse on Bermuda grass (Cynodon dactylon, Poaceae) since the previous season. G. atropunctata were collected along Wohler creek near Forestville, CA, during the summer of 2009. A single basil plant was placed in each colony. For these two species, each insect colony consisted of 40-50 adults contained in a cylindrical mesh cage. Only adult sharpshooters were used throughout this study. All of the greenhouse populations were maintained for 3-4 generations before the acquisition experiments, and were free of $X$. fastidiosa before the experiments began, as it is not transovarially transmitted (Freitag 1951).

\section{Choice experiments}

All of the experiments were performed at the Oxford Tract greenhouse facility of the University of California, Berkeley. To reduce seasonal and diurnal effects as much as possible, observations took place between 10:00 and 15:00 for all three species during sunny days between midJuly and mid-August 2009. Recorded temperatures ranged from 24 to $31^{\circ} \mathrm{C}$. All observations were made from a 2-m distance to minimize the effect of experimenter presence on leafhopper behaviour.

\section{Within-host plant site preference}

To evaluate sharpshooters' plant site preference, their response to 4-month old grapevine cuttings, Vitis vinifera, was recorded in a $20 \mathrm{~cm} \times 30 \mathrm{~cm} \times 50 \mathrm{~cm}$ plexiglass cage. A $20 \mathrm{~cm} \times 30 \mathrm{~cm}$ cardboard sheet was inserted on top of the pot so that $20 \mathrm{~cm}$ of the main shoot (including $2-3 \mathrm{~cm}$ of the old cutting below the shoot), with equal proportions of green (succulent tissue) and brown (lignified tissue), was exposed to individual insects in each trial. Leaves were removed (except 2-3 small apical leaves) to facilitate leafhopper visual evaluation of its landing site on the shoot. If no choice for shoot colour was made within the first $15 \mathrm{~min}$ of observation, the insect was given another $15 \mathrm{~min}$ and then the final choice was recorded on minute 30 . It was only for $H$. vitripennis that $33 \%$ of the tested individuals were non-responsive, as they stayed on cage walls during the $30 \mathrm{~min}$. Both insect and plant were replaced at the start of each trial and were used only once in each experiment. Experiments were conducted for the three sharpshooter species, $H$. vitripennis, $G$. atropunctata, and $D$. minerva. The experimental subject was always placed at a $15 \mathrm{~cm}$ distance from the plant base through a cloth sleeve in front of the cage. Sign test was used to compare the number of landings on green and brown parts of the plant.

\section{Controlled artificial background}

All trials for the background choice experiment were conducted in a $30 \mathrm{~cm} \times 30 \mathrm{~cm} \times 30 \mathrm{~cm}$ aluminum mesh cage. To create the green and brown backgrounds, photos of a woody stem and a leaf were printed on approximately $22 \mathrm{~cm} \times 28 \mathrm{~cm}$ pages (Photoshop CS; Adobe Systems Incorporated, San Jose, CA, USA). The two opposite cage sides were covered with either a solid brown or a solid green printed sheet. The last side (across from the observation window) was divided equally between the two colours. The front side and the top of the cage were left uncovered to facilitate the observations and to allow natural light to reach inside the cage. With the exception of a white square in the center, the bottom of the cage was covered with equal numbers of alternating brown and green $5 \times 5 \mathrm{~cm}^{2}$. The alternated squares on the bottom of the cage facilitated background selection by the experimental insects as they would walk around and stay on different checkers following their introduction onto the arena (and before jumping onto either side).

Experimental insects were gently placed onto the white arena in the center of the cage. Each trial in the artificial background experiment lasted for $15 \mathrm{~min}$. Only $6 \%$ of $H$. vitripennis were recorded as non-responsive. The time spent on each background colour, movement frequency and the first colour choice (the first visited background following introduction into the cage) were recorded. Sign ranked test was used to compare the first colour choice of the three test leafhoppers. Nonparametric Wilcoxon signed-rank was used to compare the frequency of visits to each of the green and brown backgrounds. The time spent on each background was analyzed using paired $t$ tests.

The colour reflectances of the artificial backgrounds, stem and leaf tissue, as well as the three insect species (forewing coloration) were measured. An Ocean Optics USB4000 spectrometer (Dunedin, Florida, USA) and a 1000-um reflection probe were used to measure the colour reflectance of samples placed under a Leica M205FA microscope. Spectra were recorded at 5-nm intervals from 200 to $800 \mathrm{~nm}$. The peak reflectance for green plant tissue, $G$. atropunctata, and D. minerva was recorded at $550-560 \mathrm{~nm}$. Although visually similar to a human observer, the peak reflectance for the green artificial background was recorded at $540 \mathrm{~nm}$. The peak reflectance measurements of $H$. vitripennis and the brown stem were recorded between 560 and $580 \mathrm{~nm}$. The peak reflectance of the brown artificial background was read at two peaks, 560 and $600 \mathrm{~nm}$ (the printed brown colour was a mixture of 
purple, yellow and blue pixels when placed under the microscope).

Pathogen acquisition efficiency

\section{Acquisition efficiency from plant site}

Ten $V$. vinifera grape cuttings (2-month old, var. Ruby seedless) were mechanically inoculated using $20 \mu \mathrm{l}$ of $X$. fastidiosa (STL isolate) suspended in SCP buffer (Hill and Purcell 1995). Five months later, petiole samples of all plants tested positive for the presence of the bacterium, using Polymerase Chain Reaction (PCR) detection method (Minsavage et al. 1994). Plants were 7 months old at the time of our acquisition experiment. They were regularly pruned to stay between 35 and $40 \mathrm{~cm}$ in height. Ten individuals of each of $H$. vitripennis and $G$. atropunctata were contained on separate leaves of the same plant (5 plants, in total), using mesh sleeve-cages. Simultaneously, ten $H$. vitripennis individuals were caged on the stem of each plant. Fifty G. atropunctata were caged on the brown stem tissue of another five infected grape plants (10/plant). Following a 24-h acquisition access period on infected plants, all insects were removed, decapitated, and stored at $-80^{\circ} \mathrm{C}$ for subsequent quantitative real-time PCR analysis. Only heads were stored since $X$. fastidiosa is retained in the insect foregut (Purcell et al. 1979). D. minerva was not included in the acquisition efficiency experiments on grapes as previous work has shown they are relatively nonefficient vectors of $X$. fastidiosa on grapevines (Purcell and Finlay 1979).

A generalized linear model with binomial errors was used to compare the acquisition rates (i.e. ratio of vectors that acquired the pathogen to vectors that did not) of $H$. vitripennis and $G$. atropunctata on different plant sites. This analysis was performed both with and without including the dead sharpshooters. Mortality occurred when the individuals were unable to feed on plant tissue; here, mortality was interpreted as no acquisition. The model included vector species and plant site as factors as well as the species-by-plant site interaction term. Analysis of variance (ANOVA) was used to compare the acquisition levels (i.e. number of $X$. fastidiosa cell equivalents in each infectious vector) of $H$. vitripennis and G. atropunctata. Log-transformed cell numbers were normally distributed (Kolmogorov-Smirnov test: $P>0.15$ ). Levene's test confirmed the homogeneity of variances $\left(F_{3,39}=0.54\right.$, $P=0.65)$. Our initial model included vector species, plant, feeding site (leaf vs. stem), and feeding site-by-vector species interaction. Plant was removed from our final model because of its non-significant effect $\left(F_{1,35}=0.27\right.$; $P=0.90)$. The measured head-width of $H$. vitripennis (mean (mm): $2.5(0.07), N=20)$ was 1.7 times larger than a
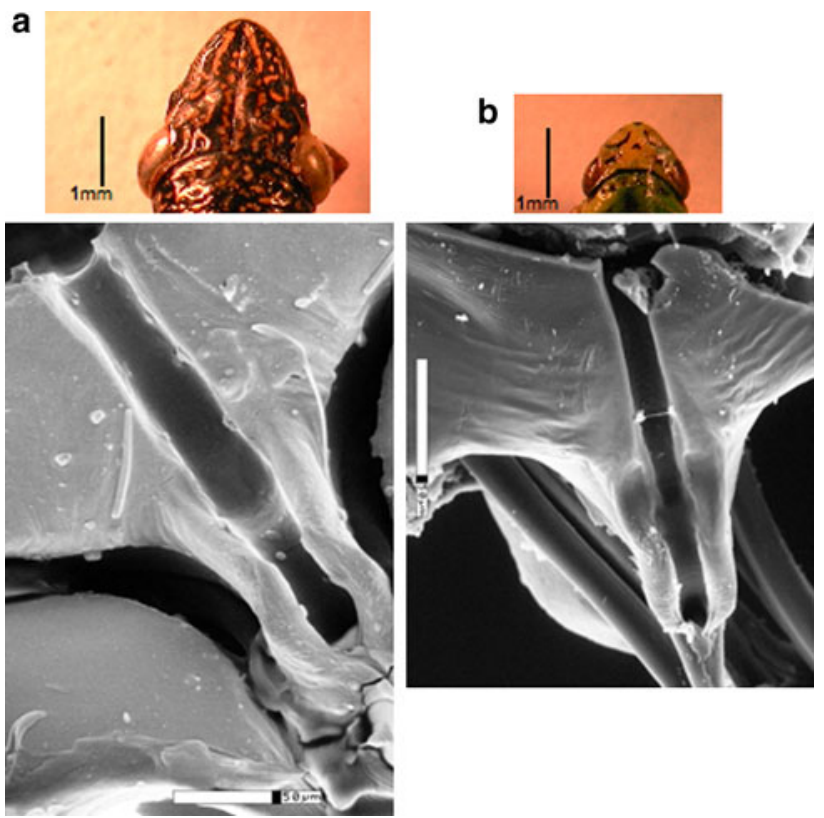

Fig. 1 Head-size comparison and scanning electron microscopy (SEM) image of the precibarium for, a Homalodisca vitripennis precibarium and, b Graphocephala atropunctata. SEM images are unpublished photos obtained in a previous study (Almeida and Purcell 2006)

that of G. atropunctata (mean (mm): $1.5(0.22), N=10)$. This number was used as a coefficient to evaluate any potential vector precibarium (the $X$. fastidiosa retention site) size effect on the bacterial acquisition level (Fig. 1a, b).

\section{Acquisition from and inoculation into artificial diet}

Acquisition through an artificial diet system was conducted following the protocol described by Killiny and Almeida (2009a). In brief, X. fastidiosa (STL strain) was grown in XFM-pectin medium at $28^{\circ} \mathrm{C}$ for 10 days. Then cells were collected and suspended in a diet solution (optical density $\left._{600}=0.4\right)$. Leafhoppers were presented with $100 \mu \mathrm{l}$ of the suspension, individually, through a single layer of parafilm, thinly stretched over a cylindrical plexiglass feeding-chamber $(14 \mathrm{~mm} \times 20 \mathrm{~mm}$-diameter $\times$ height $)$ for $3 \mathrm{~h}$ of pathogen acquisition access period. When the $3 \mathrm{~h}$ elapsed, the leafhoppers were transferred onto basil plants for a 24-h retention period. The following day insects were carefully removed and aspirated into the feeding chambers containing diet solution (no bacteria) for another 3-h feeding period (inoculation period). Heads were stored at $-80^{\circ} \mathrm{C}$ for quantitative PCR analysis. The acquisition rates of the two species were compared using Chi-square analysis. A two sample $t$ test was used to compare the acquisition levels of the two vector species. Log-transformed acquisition levels were normally distributed (KolmogorovSmirnov test: $P>0.08$ ). Levene's test verified the equality 
of variances $\left(F_{1,22}=1.0 ; P=0.32\right)$. The absolute numbers of cells inoculated into artificial diets were normally distributed (Kolmogorov-Smirnov test: $P>0.07$ ). Levene's test confirmed that variances were homogeneous between the two species $\left(F_{1,12}=1.42 ; P=0.25\right)$. All statistical analyses were performed in SPSS (ver 15).

\section{Quantitative PCR}

The $X$. fastidiosa DNA extraction process was initiated using protocol described by Daugherty et al. (2009) and was completed using a commercial protocol (QIAGENDNeasy Blood and Tissue) following the lysis step, to maximise yield. Cell numbers were estimated based on the standard curve established by Daugherty et al. (2009). The absolute quantification was performed with SYBR Green Mix (Applied Biosystems) on a 7500 real-time thermocycler (Applied Biosystems) according to the protocol described in Daugherty et al. (2009). We used primers HL5 and HL6 designed by Francis et al. (2006). In order to quantify the number of cells inoculated into the diet solution, in a novel approach, remaining buffer was collected through the parafilm sachet, following the 3-h insect feeding. The collected buffers were placed in a boiling water bath for $10 \mathrm{~min}$ and then analyzed for the quantity of $X$. fastidiosa DNA present, using quantitative PCR.

\section{Results}

\section{Choice experiments}

\section{Within-host plant site preference}

In $81 \%$ of the trials, $H$. vitripennis alighted on the brown stem tissue of grape plants (sign test (two-tailed): $P=0.007, N=21)$. In contrast, in $85 \%$ of our trials with $G$. atropunctata, the insects preferred leaf, petiole and green stem apex $(P=0.002, N=20)$. Likewise, $85 \%$ of the responding $D$. minerva individuals chose to alight on leaf, petiole and green stem apex $(P=0.002, N=20)$.

\section{Background choice experiments}

Homalodisca vitripennis alighted more often on the brown background than on the green background, as their first choice of landing site $(P=0.042, N=30)$. The total time that $H$. vitripennis spent resting on brown background was significantly longer than the time it spent on green background $(t=2.44, d f=29, P=0.021$; Fig. 2a). During the observation periods, insects frequently moved to different

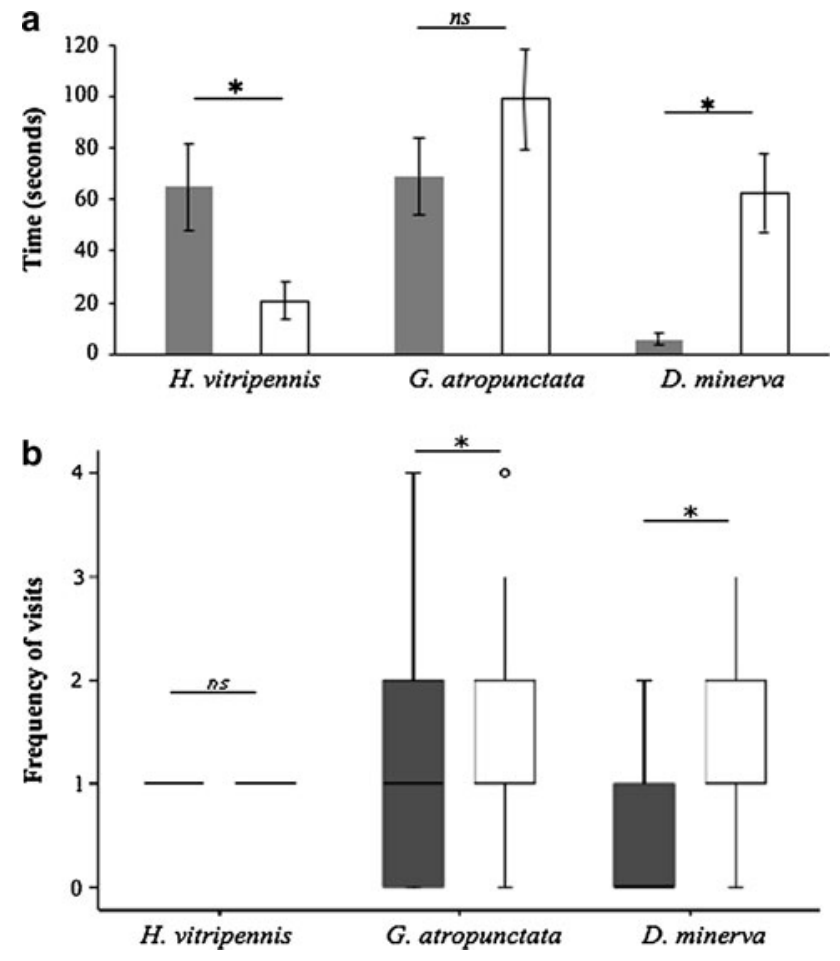

Fig. 2 The observed sharpshooters' behavior towards different colours in artificial background-choice trials. a The amount of time spent on green (empty bars) and brown (filled bars) backgrounds. Error bars represent \pm 1 SE. b Frequency of visits to each of the two background colours. Visits to the green background are shown with empty and visits to brown with filled boxes. Horizontal thick lines indicate the medians; boxes show the interquartile ranges including $50 \%$ of the values; whiskers reflect the highest and the lowest number of visits; and the circle reflects the out layer

coloured areas as well as to the top of the cage. Although $H$. vitripennis showed a tendency to visit the brown-coloured background more frequently than the green-coloured background, this difference was not statistically significant $(Z=-1.32, P=0.18$; Fig. 2 b) .

Graphocephala atropunctata preferred green as its first background choice significantly more than the brown $(P=0.038, N=40)$. G. atropuncata also showed a slight tendency to spend more time on green compared to the brown background, though this tendency was not significant $(t=1.15, d f=39, P=0.254$; Fig. 2a). The frequency of visits by $G$. atropuncata to the green background was significantly higher compared to the frequency of the visits to the brown background $(Z=2.03, P=0.042$; Fig. $2 b$ ). Similar to G. atropunctata, D. minerva chose the green background as its first landing site more frequently than the brown background $(P=0.022, N=24)$. $D$. minerva spent significantly more time on the green background compared to the brown background $(t=3.6$, $d f=23, P=0.001$; Fig. 2a). D. minerva also visited the green background more frequently compared to the brown background ( $Z=3.10, P=0.002$; Fig. $2 \mathrm{~b})$. 
Table 1 Number of vector species, their acquisition rate and the observed mortality on leaves and stems

\begin{tabular}{lllll}
\hline Vector species & Plant site & $\begin{array}{l}\text { Total number } \\
\text { of insects }\end{array}$ & $\begin{array}{l}\text { Acquisition } \\
\text { rate }\end{array}$ & Mortality rate \\
\hline Homalodisca vitripennis & Stem & 50 & 0.3 & 0.2 \\
& Leaf & 50 & 0.28 & 0.06 \\
Graphocephala atropunctata & Stem & 50 & 0.06 & 0.86 \\
& Leaf & 43 & 0.25 & 0.13 \\
\hline
\end{tabular}

Pathogen acquisition efficiency

\section{Acquisition efficiency from plant sites}

The overall bacterial acquisition rate by $H$. vitripennis was significantly higher than that by $G$. atropunctata (Wald $\chi_{1}^{2}=4.8 ; P=0.027$; Table 1$)$. However, the mortality rate of $G$. atropunctata was also significantly greater than the mortality rate of $H$. vitripennis on the brown stem tissue $\left(\chi_{1}^{2}=43.7, P<0.001\right.$; Table 1$)$. No species effect was detected when dead insects were removed from the acquisition rate analysis (Wald $\chi_{1}^{2}=0.06 ; P=0.810$ ). The proportion of individuals that acquired the pathogen was higher on leaf ( $N=25$; out of 93) than on the brown stem ( $N=18$; out of 100), though the difference was not significant (Wald $\chi_{1}^{2}=2.40 ; P=0.121$ ). The vector speciesby-feeding site interaction was of borderline statistical significance (Wald $\chi_{1}^{2}=3.57 ; P=0.058$ ). Excluding dead individuals from our analysis diminished the effect of feeding site in both vector species (Wald $\chi_{1}^{2}=0.06$; $P=0.803$ ).

Analysis of variance indicated that the pathogen acquisition level by $H$. vitripennis was significantly greater than that by $G$. atropunctata $\left(F_{1,39}=5.47, P=0.02\right.$; Fig. 3$)$. However, the significant effect of vector species on acquisition level disappeared when the numbers of cells were multiplied by the head-width coefficient

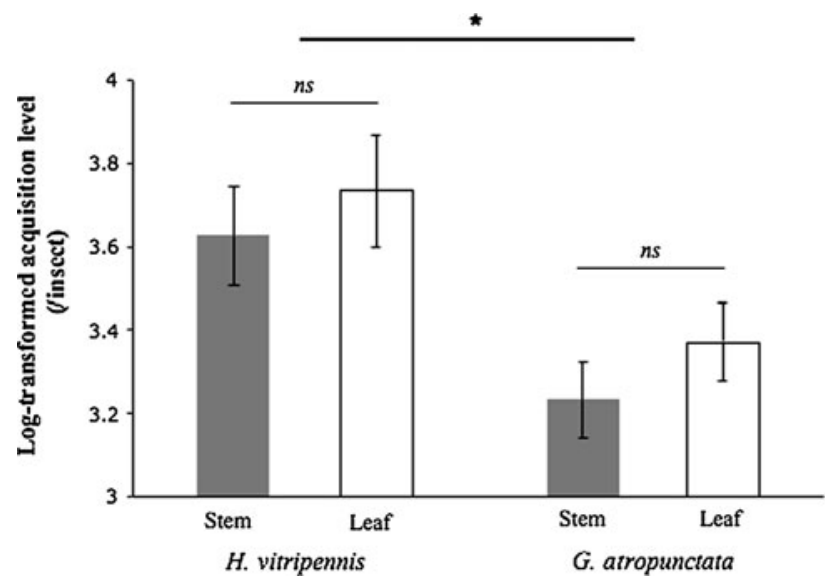

Fig. 3 Comparison of bacterial acquisition levels by Homalodisca vitripennis and Graphocephala atropunctata on the leaf (empty bars) and the stem tissue (filled bars) of grape host
$\left(F_{1,39}=1.26, P=0.20\right)$, or when the acquisition level was standardized as per $1 \mu \mathrm{g}$ of head extracted DNA $\left(F_{1,39}=0.49, P=0.48\right)$. Bacterial acquisition level by the vectors was not influenced by the feeding site, as revealed by the non-significant vector species-by-feeding site interaction $\left(F_{1,39}=0.01, P=0.93\right.$; Fig. 3$)$. However, both species showed a tendency to acquire more cells from leaves and petioles than the lignified brown stem (Fig. 3).

\section{Acquisition from and inoculation into artificial diet}

The proportion of $H$. vitripennis $(N=11$ out of 20$)$ that acquired bacterial cells through feeding on our artificial solution diet (diet solution with bacteria) was not different from that of $G$. atropunctata $(N=13$ out of 20) $\left(\chi_{1}^{2}=0.41, P=0.52\right)$. Similar to the in vivo experiments, $H$. vitripennis acquired significantly more bacterial cells compared to $G$. atropunctata $(t=2.46, \quad d f=22$, $P=0.022$; Fig. 4a). The significant difference disappeared
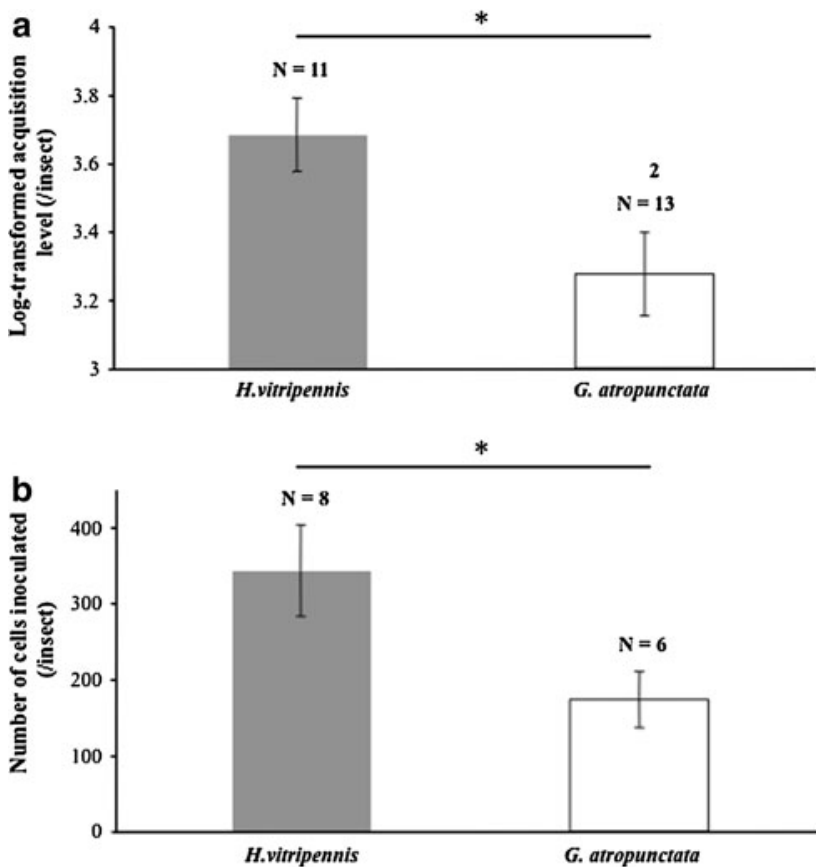

Fig. 4 Comparison of the in vitro transmission efficiency between Homalodisca vitripennis and Graphocephala atropunctata. a Bacterial acquisition level through artificial diet, and $\mathbf{b}$ the number of cells inoculated into diet solution 
as the cell numbers were adjusted for the head size $(t=1.27, d f=22, P=0.215)$. The $X$. fastidiosa-positive $H$. vitripennis also inoculated a greater number of cells into the buffer solution than did X. fastidiosa-positive G. atropunctata $(t=2.21, d f=12, P=0.047$; Fig. $4 \mathrm{~b})$. A correction for the head-size resulted in a non-significant difference between the number of cells inoculated into the diet solution by the two sharpshooter species $(t=0.83$, $d f=12, P=0.424)$.

\section{Discussion}

Background matching functions as a protective trait for diurnal feeders against visual predators (Endler 1984; Ruxton et al. 2004). This adaptive trait may also play the same role in sharpshooter leafhoppers as has been previously suggested by Purcell and Frazier (1985). Background choice may potentially govern sharpshooter exposure to pathogen as they choose to stay on plant sites containing different bacterial populations. In this study we showed that the sharpshooter leafhoppers were selective in their choice of plant site, preferring to alight on the backgrounds that closely matched their forewing coloration. The efficiency of $H$. vitripennis and $G$. atropunctata in acquiring the pathogen, however, was not influenced by that choice.

In assays with artificial backgrounds, the two greencoloured species, G. atropunctata and D. minerva, alighted and remained on the green background more often than the brown background, whereas the reverse occurred for the brown-coloured $H$. vitripennis. In his classical background choice experiments with the European pepper moth, Biston betularia (Linn.), Kettlewell (1955) used similar artificial background assays to demonstrate the existence of background matching behaviour in moths resting on tree trunks. Shortly after, Sargent (1966) showed that several common moth species match their backgrounds during the day, when they are most exposed to visual predators. Future studies with visual predators are needed to verify the protective function of the background matching behaviour in leafhoppers.

Sharpshooter leafhoppers are polyphagous and exploit numerous hosts ranging from weedy to woody plant species (e.g. Hewitt et al. 1946; Purcell 1976; Mizell et al. 2008). Host switching has been proposed to be a behavior that has evolved in sharpshooters as a means to obtain essential nutrients for somatic maintenance and reproduction from the poor nutritional content of xylem sap (Andersen et al. 1992; Redak et al. 2004; Mizell et al. 2008). Xylem sap quality is also affected by various environmental variables throughout the season (Mizell et al. 2008) and thus tissue color per se does not predict vector choice of host-plant. Background matching behavior may rather explain leafhopper plant site preference following the initial host selection. G. atropunctata and D. minerva may associate the perceived green reflectance with plant tissue that they can pierce through and initiate ingestion. The failure of $G$. atropunctata to feed on the lignified stem tissue was supported by its $86 \%$ mortality. Likewise, $H$. vitripennis may associate brown coloration with stem tissue-their preferred feeding site on grapevines (Redak et al. 2004). The relatively large body size of $H$. vitripennis enables them to afford the energetic cost associated with extracting sap against the high negative tension of xylem (see Novotny and Wilson 1997) and piercing through woody stem tissue, where they have access to larger xylem vessels than those in young and smaller branches (Zimmermann 1983). This is in spite of their ability to feed on succulent tissues. Indeed, it has been observed that $H$. vitripennis feeds on the succulent tissue of peach trees (Prunus persica), which is a poor host for this vector species (Mizell and French 1987). Therefore, the ability to feed on the woody stem may be conditiondependent. Furthermore, the woody stem may provide the relatively large-sized $H$. vitripennis with better protection from predators at a distance via concealment on a dark and rough surface. There, they also have the opportunity to behaviourally evade an approaching predator, by moving quickly behind the stem. This evasive behaviour is performed en masse by this species (Mizell personal communication).

The feeding site did not influence bacterial acquisition rate. However, the overall acquisition rate by $H$. vitripennis was significantly higher than that by $G$. atropunctata. The observed between-species difference was due to the high mortality of $G$. atropunctata on the stem tissue. This was confirmed when removing dead individuals from our analysis resulted in a non-significant species effect. G. atropunctata needs to feed frequently as it dies within day-long starvation periods under greenhouse conditions (unpublished data). H. vitripennis acquired significantly more bacterial cells than did G. atropunctata, regardless of the plant site they were feeding on. The non-significant feeding-site by species interaction, however, needs to be interpreted with caution, as the high mortality rate of G. atropuncata on lignified stem tissue (Table 1) limits the number of samples for acquisition levels from the stem. Our overall conclusion of the acquisition levels was confirmed by the follow-up in vitro acquisition experiments. Subsequently, $H$. vitripennis inoculated a greater number of cells ('inoculation level') into the artificial diet compared to $G$. atropunctata. Thus, the observed higher transmission efficiency of $G$. atropunctata compared to $H$. vitripennis in the grape host (Redak et al. 2004; Daugherty and Almeida 2009) may not be due to their differential exposure to the pathogen. Hill and Purcell (1995) showed that in grapevines 
transmission efficiency is independent of the number of $X$. fastidiosa in G. atropunctata heads. Likewise, Jackson et al. (2008) suggested that the inoculation level into Chrysanthemum host was not correlated with the amount of bacteria within the vector $H$. vitripennis. These previous studies in conjunction with our findings suggest that transmission efficiency of $X$. fastidiosa is probably not a factor of the acquisition level of the vectors. Indeed only as low as one hundred cells are sufficient to inoculate a healthy plant (Hill and Purcell 1995) - a number far less than the recovered cells from each insect head following a 24-h retention period (Fig. 3). Estimated cell numbers in the heads in this study were within the same range as those reported by Killiny and Almeida (2009b), from whose data a generation time of $7-8 \mathrm{~h}$ for $X$. fastidiosa inside G. atropunctata can be estimated.

Our findings, however, do not undermine previous studies on $X$. fastidiosa transmission, which suggest that transmission efficiency is a factor of the plant site where acquisition occurs (Almeida and Purcell 2003; Daugherty et al. 2010). Horticultural practices such as regular pruning of relatively young grapevines (7-month old cuttings) may have unintentionally manipulated the expected higher bacterial population in petioles and leaves compared to the stem (Krivanek and Walker 2005). However, this still does not explain the observed higher bacterial acquisition levels by $H$. vitripennis relative to $G$. atropunctata-which seemed to be a factor of vector size, and quite possibly, the volume of sap ingested.

The differences in transmission efficiency of G. atropunctata and $H$. vitripennis may result from differences between their plant site preferences as well as their probing behaviours (see Backus et al. 2005) during the inoculation stage. It should be acknowledged that $X$. fastidiosa transmission is rather complex and it may be simplistic to assume that evaluating acquisition and/or inoculation levels per se are enough to explain transmission efficiencies of different vectors. For example, the bacterial strain and its interactions with the host (Prado et al. 2008) and/or the number of the inoculation events by vectors (Daugherty et al. 2009) are factors that can influence transmission efficiency. Moreover, from a biochemical point of view, higher populations of $X$. fastidiosa cells in plant tissue result in elevated levels of diffusible signaling molecules (DSF), which induce an adhesive phase of the pathogen (Newman et al. 2004; Chatterjee et al. 2008a) - a crucial stage for vector colonization (Chatterjee et al. 2008b; Killiny and Almeida 2009a). Therefore, vector preference for feeding-sites with high bacterial populations, i.e. leaves and petioles, may expose them to the adhesive phase of $X$. fastidiosa, which may be more important in a successful transmission than the total number of cells acquired from and/or inoculated into the host.
Xylella fastidiosa attaches to the leafhoppers' foregut while they feed on an infected host plant (Almeida and Purcell 2006). H. vitripennis is a larger sharpshooter than $G$. atropunctata and thus provides about twice as much surface area in the precibarium for $X$. fastidiosa cells to attach and multiply (Fig. 1). The difference in acquisition levels between the two species disappeared when the number of cells in G. atropunctata heads was multiplied by the vector head-size coefficient, and also when bacterial numbers were quantified in a fixed amount of extracted DNA from insect heads. Thus, the surface size of the insect foregut may act as a constraint on the numbers of the cells that can attach during the feeding and later colonize the precibarium during retention.

In sum, we showed that the three tested sharpshooters prefer to alight on plant site that matches their forewing coloration, but this behaviour had no effect on the bacterial acquisition level by the different vectors on the host plant. Our in vivo experiments suggested that bacterial acquisition level might be size related. Subsequent in vitro experiments in the absence of plant host, and under controlled conditions, provided support for the contention that size may be a key factor in determining acquisition and inoculation levels. Our findings do not rule out the possibility of a link between pathogen acquisition level and transmission efficiency where ecological and environmental constraints affect bacterial populations within plants or vector behaviours. More studies are necessary for the evaluation of vector interactions with host plants at both mechanical and biochemical levels during the inoculation process.

Acknowledgments We would like to thank A.H. Purcell, M. P. Daugherty, J. Jedlicka, D. Ling, and L. Bittleston for their comments on an earlier version of our manuscript. We thank A. Sharma and K. Li for quantitative PCR assistance. Also thanks to Foundation Plant Services for grapevine cuttings, R. Krugner for providing us with the glassy-winged sharpshooters, and D. Elias, for helping us in measuring the colour reflectance by providing all related equipment. Funding for this project was provided by USDA-CSREES and CDFA Pierce's Disease Research Program to co-author R.P.P.A.

Open Access This article is distributed under the terms of the Creative Commons Attribution Noncommercial License which permits any noncommercial use, distribution, and reproduction in any medium, provided the original author(s) and source are credited.

\section{References}

Almeida RPP, Backus EA (2004) Stylet penetration behaviors of Graphocephala atropunctata (Say) EPG waveform characterization and quantification. Ann Entomol Soc Am 97:838-851

Almeida RPP, Purcell AH (2003) Transmission of Xylella fastidiosa to grapevines by Homalodisca coagulata (Hemiptera: Cicadellidae). Econ Entomol 96:264-271 
Almeida RPP, Purcell AH (2006) Patterns of Xylella fastidiosa colonization on the precibarium of sharpshooter vectors relative to transmission to plants. Ann Entomol Soc Am 99: $884-890$

Alvarez AE, Garzo E, Verbeek M, Vosman B, Dicke M, Tjallingii WF (2007) Infection of potato plants with potato leafroll virus changes attraction and feeding behaviour of Myzus persicae. Entomol Exp Appl 125:135-144

Andersen PC, Brodbeck BV, Mizell RF (1992) Feeding by the leafhopper, Homalodisca coagulata, in relation to xylem fluid chemistry and tension. J Insect Physiol 38:611-622

Backus EA, Habibi J, Yan F, Ellersieck M (2005) Stylet penetration by adult Homalodisca coagulata on grape: electrical penetration graph waveform characterization, tissue correlation, and possible implication for transmission of Xylella fastidiosa. Ann Entomol Soc 98:787-813

Blua MJ, Perring TM (1992) Effects of zucchini yellow musaic virus on colonization and feeding behavior of Aphis gossypii (Homoptera: Aphididae) alatae. Environ Entomol 21:578-585

Burger JC, Patten MA, Rotenberry JT, Redak RA (1999) Foraging ecology of the California gnatcatcher deduced from fecal samples. Oecologia 120:304-310

Chai P, Srygley RB (1990) Predation and the flight, morphology, and temperature of neotropical rain-forest butterflies. Am Nat 135: $748-765$

Chatterjee S, Wistorm C, Lindow SE (2008a) A cell-cell signaling sentor is required for virulence and insect transmission of Xylella fastidiosa. Proc Natl Acad Sci USA 105:2670-2675. doi:10.1073/ pnas.0712236105

Chatterjee S, Almeida RPP, Lindow SE (2008b) Living in two worlds: the plant and insect lifestyles of Xylella fastidiosa. Ann Rev Phytopathol 46:243-271

Cloarec A, Joly D (1988) Choice of perch by the water stick insect. Behav Process 17:131-144

Cott HB (1940) Adaptive coloration in animals. Meuthen \& Co, London

Daugherty MP, Almeida RPP (2009) Estimating Xylella fastidiosa transmission parameters: decoupling sharpshooter number and feeding period. Entomol Exp Appl 139:84-92. doi:10.1111/ j.1570-7458.2009.00868.x

Daugherty MP, Bosco D, Almeida RPP (2009) Temperature mediates vector transmission efficiency: inoculum supply and plant infection dynamics. Ann Appl Biol 155:361-369. doi:10.1111/ j.1744-7348.2009.00346.x

Daugherty MP, Lopes J, Almeida RPP (2010) Vector within-host preference mediates transmission of a heterogeneously distributed pathogen. Ecol Entomol 35:360-366. doi:10.1111/j.13652311.2010.01189.x

Dekker T, Takken W, Knols BGJ, Bouman E, van de Laak S, Bever A, Huisman PW (1998) Selection of biting sites on a human host by Anopheles gambiae s.s., An. arabiensis and An. quadriannlatus. Entomol Exp Appl 87:295-300

Endler JA (1984) Progressive background matching in moths, and a quantitative measure of crypsis. Biol J Linn Soc 16:25-31

Fisher RA (1930) The genetic theory of natural selection. The Clarendon Press, Oxford

Fournier V, Hagler J, Daane K, de Leon J, Groves R (2008) Identifying the predator complex of Homalodisca vitripennis (Hemiptera: Cicadellidae): a comparative study of the efficacy of an ELISA and PCR gut content assay. Oecologia 157:629-640. doi:10.1007/s00442-008-1095-x

Francis M, Lin H, Cabrera-La Rosa J, Doddapaneni H, Civerolo EL (2006) Genome-based PCR primers for specific and sensitive detection and quantification of Xylella fastidiosa. Eur J Plant Pathol 115:203-213
Freitag JH (1951) Host range of the Pierce's disease virus of grapes as determined by insect transmission. Phytopathology XLI: 920-934

Hatle JD, Salazar BA, Whiteman DW (2002) Survival advantage of sluggish individuals in aggregation of aposematic prey, during encounters with ambush predators. Evol Ecol 16:415-431

Hewitt WB, Houston BR, Frazier NW, Freitag JH (1946) Leafhopper transmission of the virus causing Pierce's disease of grape and dwarf of alfalfa. Phytopathology 36:117-128

Hill BL, Purcell AH (1995) Multiplication and movement of Xylella fastidiosa within grapevine and four other plants. Phytopathology $85: 1368-1372$

Hill BL, Purcell AH (1997) Populations of Xylella fastidiosa in plants required for transmission by an efficient vector. Phytopathology 87:1197-1201

Hopkins DL, Purcell AH (2002) Xylella fastidiosa: cause of Pierce's disease of grapevine and other emergent diseases. Plant Dis 86: 1056-1066

Ioannou CC, Krause J (2009) Interactions between background matching and motion during visual detection can explain why cryptic animals keep still. Biol Lett 5:191-193. doi:10.1098/rsbl. 2008.0758

Jackson BC, Blua MJ, Bextine B (2008) Impact of duration versus frequency of probing by Homalodisca vitripennis (Hemiptera: Cicadellidae) on inoculation of Xylella fastidiosa. Econ Entomol 101:1122-1126. doi:10.1603/0022-0493(2008)101[1122:IODVFO] 2.0.CO; 2

Kettlewell HBD (1955) Recognition of appropriate backgrounds by the pale and black phases of Lepidoptera. Nature 175:943-944

Killiny N, Almeida RPP (2009a) Host structural carbohydrate induces vector transmission of a bacterial plant pathogen. Proc Natl Acad Sci USA 106:22416-22420. doi:10.1073/pnas.0908562106

Killiny N, Almeida RPP (2009b) Xylella fastidiosa afimbrial adhesins mediate cell transmission to plants by leafhopper vectors. Appl Environ Microbiol 75:521-528. doi:10.1128/AEM.01921-08

Kilpatrick AM, Kramer LD, Jones MJ, Marra PP, Daszak P (2006) West Nile virus epidemics in north America are driven by shifts in mosquito feeding behavior. PLoS Biol 4:606-610. doi: 10.1371/journal.pbio.0040082

Krivanek AF, Walker MA (2005) Vitis resistance to Pierce's disease is characterized by differential Xylella fastidiosa populations in stems and leaves. Phytopathology 95:44-52

Lopez R, Mizell RF, Andersen PC, Brodbeck BV (2003) Impact of natural enemies on populations of the glassy-winged sharpshooter, Homalodisca coagulata (Say) in north Florida. In: VanDriesche $\mathrm{R}$ (ed) First international symposium on biological control of arthropods. USDA For Ser Pub FHTET-03-05, pp 484-486

Marucci RC, Lopes JRS, Vendramim JD, Corrente JE (2004) Feeding site preference of Dilobopterus costalimai Young and Oncometopia facialis Signiret (Hemiptera: Cicadellidae) on citrus plants. Neutrop Entomol 33:759-768

McElhany P, Real LA, Power AG (1995) Vector preference and disease dynamics: a study barely yellow dwarf virus. Ecology 76:444-457

Minsavage GV, Thompson CM, Hopkins DL, Leite RMVBC, Stall RE (1994) Development of polymerase chain reaction protocol for detection of Xylella fastidiosa in plant tissue. Phytopathology $84: 456-461$

Mizell RF, French WJ (1987) Leafhopper vectors of phony peach disease: feeding site preference and survival on infected and uninfected peach, and seasonal responses to selected host plants. J Entomol Sci 22:11-22

Mizell RF, Tipping C, Andersen PC, Brodbeck BV, Hunter WB, Northfield T (2008) Behavioral model for Homalodisca vitripennis (Hemiptera: Cicadellidae) optimization of host plant 
utilization and management implications. Environ Entomol 37:1049-1062

Newman KL, Almeida RPP, Purcell AH, Lindow SE (2004) Cell-cell signaling controls Xylella fastidiosa interactions with both insects and plants. Proc Natl Acad Sci USA 101:1737-1742. doi: 10.1073/pnas.0308399100

Novotny V, Wilson MR (1997) Why are there no small species among xylem-sucking insects? Evol Ecol 11:419-437

Prado SS, Lopes JRS, Demetrio CGB, Borgatto AF, Almeida RPP (2008) Host colonization differences between citrus and coffee isolates of Xylella fastidiosa in reciprocal inoculation. Scientia Agricola 65:251-258

Purcell AH (1976) Seasonal changes in host plant preference of the blue-green sharpshooter Hordnia circellata (Homoptera: Cicadellidae). Pan-Pac Entomol 52:33-37

Purcell AH, Finlay A (1979) Evidence for noncirculative transmission of Pierce's disease bacterium by sharpshooter leafhoppers. Phytopathology 69:393-395

Purcell AH, Frazier NW (1985) Habitat and dispersal of the principal leafhopper vectors of Pierce's Disease bacterium in the San Joaquin valley. Hilgardia 53:1-32

Purcell AH, Saunders SR (1999) Glassy-winged sharpshooter expected to increase plant disease. Calif Agric 53:26-27

Purcell AH, Finlay AH, McLean DL (1979) Pierce's disease bacterium: mechanism of transmission by leafhopper vectors. Science 205:839-841

Redak RA, Purcell AH, Lopes JRS, Blua MJ, Mizell RF, Andersen PC (2004) The biology of xylem fluid-feeding insect vectors of Xylella fastidiosa and the relation to disease epidemiology. Annu Rev Entomol 49:243-270. doi:10.1146/annurev.ento.49.061802. 123403

Ruxton GD, Sherratt TN, Speed MP (2004) Avoiding attack: the evolutionary ecology of crypsis, warning signals and mimicry. Oxford University Press, Oxford

Saracco P, Bosco D, Vertti F, Marzachi C (2005) Quantification over time of chrysanthemum yellows phytoplasma (16Sr-I) in leaves and roots of the host plant Chrysanthemum carinatum (Schousboe) following inoculation with its insect vector. Physiol Mol Plant Pathol 67:212-216. doi:10.1016/j.pmpp.2006.02.001
Sargent TD (1966) Background selection of geometrid and noctuid moths. Science 154:1674-1675

Sherratt TN, Rashed A, Beatty CD (2004) The evolution of locomotory behavior in profitable and unprofitable simulated prey. Oecologia 138:143-150

Shriram AN, Ramaiah KD, Krishnamoorthy K, Sehgal S (2005) Diurnal pattern of human-biting activity and transmission of subperiodic Wuchereria bancrofti (Filariidea: Dipetalonematidae) by Ochleroatus niveus (Diptera: Culicidae) on the Andaman and Nicobar islands of India. Am J Trop Med Hyg 72:273-277

Sisterson MS (2008) Effects of insect-vector preference for healthy or infected plants on pathogen spread: insights from a model. Econ Entomol 101:1-8. doi:10.1603/0022-0493(2008)101[1:EOIPFH] 2.0.CO;2

Sorenson JT, Grill RT (1996) A range extension of Homalodisca coagulata (Say) (Hemiptera: Clypeorrhyncha: Cicadellidae) to southern California. Pan-Pac Entomol 72:160-161

Stamp NE, Wilkens RT (1993) On the cryptic side of life: being unapparent to enemies and the consequences for foraging and growth of caterpillars. In: Stamp NE, Casey TM (eds) Caterpillars, ecological and evolutionary constraints on. Chapman and Hall, New York, pp 283-330

Suttle KB, Hoddle MS (2006) Engineering enemy-free space: an invasive pest that kills its predator. Biol Invasions 8:639-649. doi:10.1007/s10530-005-1856-y

Tatineni S, Sagaram US, Gowda S, Robertson CJ, Dawson WO, Iwanami T (2008) In planta distribution of 'Candidatus Liberibacter asiaticus' as revealed by polymerase chain reaction (PCR) and real-time PCR. Phytopathology 98:592-599. doi:10.1094/ PHYTO-98-5-0592

Tsai JH, Wang JJ, Liu YH (2002) Seasonal abundance of the asian citrus psyllid, Diaphorina citri (Homoptera: Psyllidae) in southern Florida. Fla Entomol 85:446-451

Turell MJ, O'Guinn ML, Dohm DJ, Jones JW (2001) Vector competence of North American mosquitoes (Diptera: Culicidae) for West Nile virus. J Med Entomol 38:130-134

Zimmermann MH (1983) Xylem structure and the ascent of sap. Springer, Heidelburg 